\title{
MOTIVATION, STRATEGY, DIGITAL MARKETING: MSME SUREFIRE MOVES TO SURVIVE IN THE MIDST OF THE COVID-19 PANDEMIC
}

\author{
Rizky Firmansyah $^{1}$, Mochammad Galih S Wicaksono ${ }^{2}$, Dwi Narulia ${ }^{3}$, Ridoni \\ Fardeni Harahap ${ }^{4}$, Annisa Puspita Amalia ${ }^{5}$, \\ 1,2,3,4,5 Accounting Department, Universitas Negeri Malang, Malang, Indonesia \\ ${ }^{1}$ rizky.firmansyah.fe@um.ac.id, ${ }^{2}$ mgalihsatriyow@gmail.com, ${ }^{3}$ dwi.narullia.fe@um.ac.id, \\ ${ }^{4}$ ridoni.fardeni.fe@um.ac.id, ${ }^{5}$ alys849@gmail.com
}

\begin{abstract}
This service activity aims to analyze the needs and build a digitalization mindset for MSMEs in Malang City in facing the challenges of the Covid-19 Pandemic. Digital marketing strategies can be a bridge for MSMEs to reach a wider target market, so an interpersonal approach is needed to encourage business people to renew targeted marketing strategies. The method of implementing this activity consists of three stages, namely pre-implementation, implementation and post-implementation. The findings on the activity contain interesting facts, including MSMEs in Malang City do not experience capital problems, cash flow uncertainty causes a reduction in production activities, features on online platforms have not been used optimally and difficulties in compiling interesting content that can create interaction with the target market. Significant results were shown by MSME actors after participating in counseling and training activities, namely MSME actors were able to determine an online platform that could support their marketing system and some MSME actors were able to create interactions with consumers through digital activation to the purchase process from consumers. Apart from that, there are still many things that must be improved by MSME actors, especially in improving the quality of human resources and the digital marketing system.
\end{abstract}

Keywords: MSME, business, digital marketing, covid-19 pandemic

\section{A. Introduction}

Since the corona virus outbreak in Indonesia, various sectors have experienced a weakening which hampered the pace of economic growth. The Central Statistics Agency of the Republic of Indonesia reported that economic growth in the first quarter of 2021 experienced a contraction of minus $0.74 \%$ from the previous year (Kompas, 2021). Meanwhile, the Ministry of Cooperatives and SMEs stated that the number of MSMEs in Indonesia reached 62.9 million. This figure is stated by the Director General of Taxes (DGT) that MSMEs are the backbone of the Indonesian economy. According to him, MSMEs represent 98.8 percent of business units in the economy and 
employment of around 96.99 percent of the total workforce in Indonesia. Even MSMEs contributed 60.3 percent of the National Gross Domestic Product (GDP) (Desrianto, 2019). Thus, MSMEs need special attention, considering that they are the largest contributor to GDP and are able to absorb labor (Ita, 2020; Kompas, 2020; Pratiwi, 2020).

In difficult times like today, risks will cover the activities of business actors. This is due to the uncertainty of situations and conditions that cannot be predicted, as a result, every decision taken carries certain risks (Mandasari et al., 2021). Based on the results of a survey conducted in Thaha's research (2020) it was stated that $50 \%$ of MSMEs indicated that they would go out of business due to the Covid-19 pandemic. One of them is due to regulations set by the government that can affect productivity levels and even stop activities temporarily. Efforts to optimize the minimum possible risk, MSMEs need a change in strategy by taking into account the management business cycle (Santoso \& Mujayana, 2021). The management business cycle is a planning and organizing business cycle that can describe the classification of business types by line of business, so that it can be the basis for measuring business opportunities during the Covid-19 pandemic (Asmini et al., 2020).

Malang City is one of the strategic areas for developing business ventures. Based on data from Bank Indonesia's Malang Branch Office, in January 2019 credit distribution reached $15,491 \mathrm{~T}$. The share of MSME credit in Malang has exceeded the national regulation of $20 \%$ of total bank lending. This means that there is trust and a good business climate in the Malang area (Arifin, 2019). Different conditions since the outbreak of the corona virus, all business actors have experienced sluggishness, but the most affected are business actors in the arts sector. This is due to the closure of tourist attractions which causes the number of visitors to decrease.

Sanggar Kreatif Mamalia (SKM) is one of the SMEs in the field of arts and crafts in the city of Malang. The products offered include necklaces, bracelets, piggy banks, and others. As one of the largest MSMEs in the arts sector in Malang City that is able to 
adapt to current conditions, SKM is in the spotlight for business actors in the same field. SM as the owner revealed that his business can survive because it has implemented an online sales system for a long time. Through the development of an online system, SKM has a wider market reach. Not only regional and national, but able to penetrate the international market. The system that has been built by SKM should be a model for similar business actors. However, what makes the difference between SMEs in this field is that they feel unprepared when the corona virus outbreak comes. They tend to choose to stop temporarily and replace or are looking for an alternative type of business. Choosing a new type of business actually brings new risks because in building a business system there are many stages that must be passed so that the products offered are able to penetrate the target market (Amalia \& Puspaningtyas, 2021). Therefore, optimization of the available resources needs to be done by formulating new and adaptive strategies, the selection of new types of business is not a solution in order to be able to survive in the midst of the Covid-19 pandemic.

Based on the explanation above, this paper aims to improve and at the same time build the mindset of MSME actors towards digitalization. This is intended to provide knowledge and practical experience for SMEs in the arts sector in Malang City, so that their existence and activities are expected to run as they should. This activity uses an interpersonal skills approach.

\section{B. Method of Implementation}

The importance of building a mindset in developing a business towards digitalization, with the intention that MSME actors are able to survive in the midst of the Covid-19 pandemic situation. The interpersonal approach chosen is intended to build motivation for MSME actors and provide a change in strategy towards digitalization (Digital Marketing) which is later referred to in this paper as "Jurus Jitu MSD". While the target of this activity is MSME actors in Malang City who develop arts and crafts businesses. Data collection techniques through observation, interviews and documentation. 
The implementation of this activity is carried out through several series of activities, namely preimplementation, implementation and post-implementation. In the first stage, observations and interviews were carried out to dig up data/information, as well as analyze the need to map the potentials and problems faced by MSME partners and actors in the arts and crafts in the midst of a pandemic situation. Based on these activities, solutions to problems and planning related to workshop activities were obtained which consisted of counseling and training activities. The second stage, the implementation of the workshop, aims to provide an injection of motivation and provision of basic materials on digital marketing and strategy. In this activity, the authors present practitioners in their fields as well as validators in the implementation of the Forum Discussion Group (FGD). In the last stage, the author provides assistance for MSME actors within a certain period of time. These mentoring activities can be the basis for measuring and evaluating the level of achievement of the program that has been made by the author.

\section{Result and Discussion}

As the spearhead of the country's economy, MSMEs are able to contribute greatly to the country. MSMEs are able to absorb a lot of the workforce and encourage increased productivity which in turn can boost the Gross Domestic Product. In an effort to maintain the existence of MSMEs during the Covid-19 pandemic, an interpersonal approach is needed to build an optimistic mindset and believe that they are able to survive in the midst of the current situation. SMEs in the arts and crafts sector were chosen because they are one of the most affected parties. They can't produce normally because the product is stuck and the amount of demand is decreasing (Suryaningprang et al., 2019).

The main problem faced by MSME actors is the aspect of readiness to welcome the new normal era which is not supported by more stable capabilities and strategy updates. They feel they are in a comfort zone, with a traditional marketing system. Through 
this community service activity, the author intends to introduce and lead them towards digitalization. This is because technology becomes a bridge between sellers and buyers, so it is necessary to build a strong foundation between the two relationships.

At the initial stage, the authors conducted observations and interviews with the aim of digging up information related to the conditions and problems faced by MSME actors. The author carried out a mapping of needs analysis based on the data and facts collected. Several interesting facts have been found, namely (1) the MSME community in the arts and crafts sector has easy access to capital from Pegadaian, (2) original products that are still produced manually,

decreased demand and income, (4) product marketing model done in a simple way, (5) the digital marketing approach has not been carried out optimally.

The convenience of this capital loan is due to the good relationship between the Sanggar Kreatif Mamalia (SKM) and the Pegadaian. Referring to this, actually SMEs do not need to worry about capital because at any time they can take this opportunity. This is as stated by SM as the owner:

"Thanks to this collaboration, our community doesn't have to worry about capital. The conditions are easy, they are only asked to save and if at any time they need funds they can borrow it."

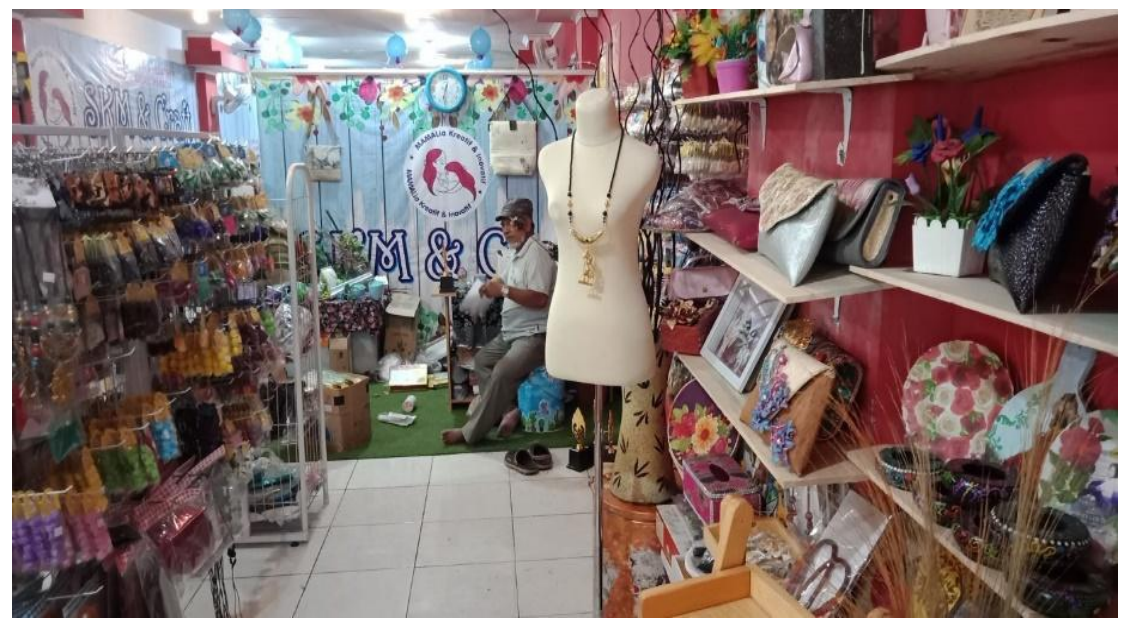

Figure 1. MSME products

The effectiveness in MSME patience in making a work. Every day, production activities is still relatively each individual is able to produce at low, because it requires accuracy and least one product, which depends on 
the shape of the product. According to RA as MSME actors, they still profitable because the materials used are used goods which they can turn into valuable and useful products. Since the pandemic, the number of requests has decreased drastically over a long period of time and they even have difficulty selling their products. AP revealed that he is used to doing simple sales and he finds it difficult to market products online effectively and efficiently. Another thing MM said that he found it difficult to get potential buyers with a digital marketing system. Based on this, the author makes a workshop activity with the aim of providing understanding and practical experience regarding digital marketing techniques. The author considers that this type of business has potential, but there needs to be improvements both in the system and improving the quality of human resources.

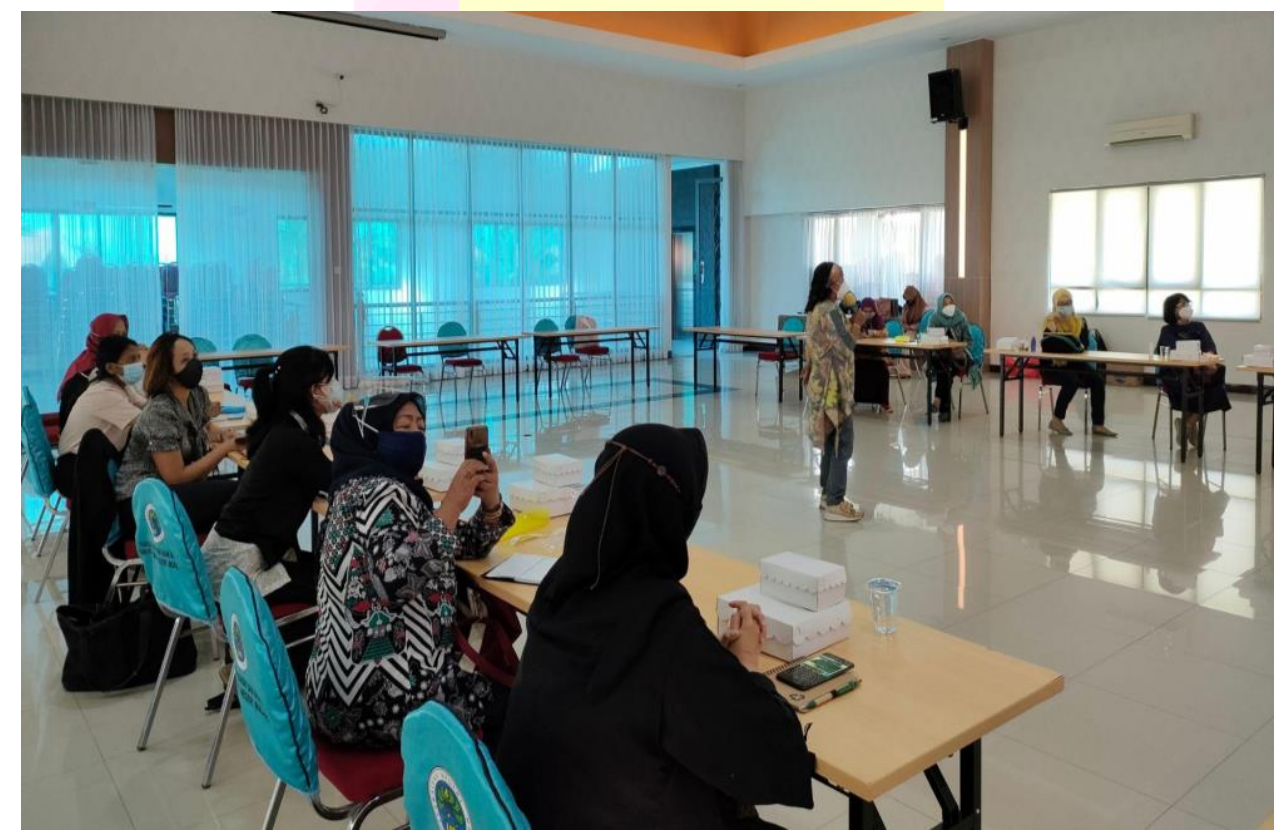

Figure 2. Focus Group Discussion 
In the implementation phase, a workshop was held which was attended by 30 participants and 2 experts in their field. The first material is about introducing the basics of digital marketing and building a mindset on the importance of digital marketing in the current era, while the second material is about digital marketing strategies and optimizing the use of features and applications that are not paid. When the first material was delivered by SM as the owner of the SKM, the participants seemed enthusiastic about receiving the material he presented. In his explanation, the selection of digital marketing in the new normal era has benefits and advantages, namely business actors can determine the target market, can reduce promotional costs, have wider market reach and easier communication with consumers, and are not limited in space and time.

"Never stop to move and try. If you feel that your sales are stuck, it means that you are asked to keep thinking and looking for ways to solve the problems you are facing. Digital marketing can be an alternative in a situation like this, do you have a product? who are diligent in their promotions, always update every day, don't be stingy to introduce products. If this goes on consistently, you can see the results."

The second material is about digital marketing strategy by DK as a digital marketing practitioner. He conducted a survey on participants regarding the challenges that participants are currently facing during the Covid-19 pandemic. Some of the facts that have been disclosed by participants, namely the number of requests decreased and the difficulty of getting consumers, unstable cash flow caused by market uncertainty, higher costs than revenue, and unpreparedness in optimizing the use of features in their applications. DK is of the opinion that:

"It doesn't matter if you can only use WA, Messenger, Telegram, Facebook, and others applications. Your current task, please study the application, so that its use can be optimal and try it out."

Optimization in the selection of certain applications, can support and improve a more regular digital marketing system. The results of the next survey, it is known that the selection of digital marketing strategies for MSME actors is very varied, there is a combination of using Instagram with Whatsapp, Facebook, Google 
business, and websites. Based on a survey agency for internet data usage, it shows that internet users have increased since the Covid-19 outbreak. Based on this data, MSME players must always be updated on trends and what the market needs today. Likewise, determining the application that is most in demand at this time, so that the target market is right on target and it will be a waste if there is no advertising but there is a market.

The DK stated that there are four stages in the digital marketing process, namely (1) understanding the character of the target market, (2) creating targeted advertising content, (3) the target liking the advertised content, and (4) the target market making a purchase. The flow seems simple, but it must be followed by the capacity and ability to compose interesting content. The orientation of business actors must focus on brand loyalty, which focuses on meeting consumer needs and desires supported by product quality, so as to increase consumer awareness of the products offered. They will definitely buy it again and will recommend it to the people around it or often called Word of Mouth (WOM).
Things that need to be done by MSME actors before determining the right digital marketing strategy, including:

1. Conduct research as well as market persona and market segmentation

2. Knowing the problem and able to answer consumer needs

3. Conduct competitor research and benchmarks

The research data can be obtained from the buyer's information data, then analyzed to find out the buyer's character, it can be seen from his likes, background, and buying experience. If you need to do a short interview with buyers who have repeated orders, buy once or just ask. In addition, competitor research is needed to become a benchmark and evaluation material, so that MSME actors can realize things that can be the basis for measuring their performance and productivity.

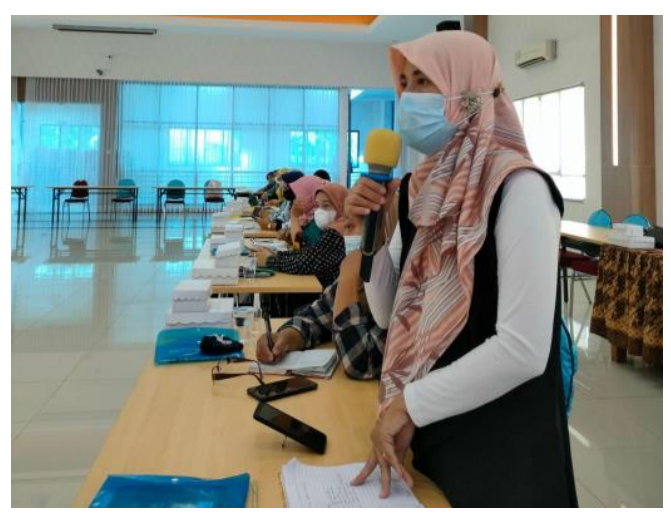

Figure 3. Q\&A session with experts 
CA as the MSME actor revealed that these things have never been done at all in analyzing the target market. The current focus is to continue to innovate and improve product quality. Responding to this, the DK is of the opinion that if MSME actors only focus on products, it is not wrong, but also efforts to improve the digital marketing system. In building a digital marketing system, the main thing that needs to be done is to set goals. Write down what your marketing goals are and what you want to achieve. The next step is to build a digital profile and digital activation.

In building a profile, determine the digital platform that can be used and research the number of users so that we know who is the target market. If you choose the Instagram application, the things that need to be improved can be starting from the contents of the Instagram bio clearly, highlighting the value in our products, then creating interesting content for the feed, Instagram story, reels and IG TV features. In creating content, we can look at the original side of the work and follow the trends that are developing. There are many more platforms that can be used, such as business websites, Google My Business, Marketplace, and various social media and chats.

We can do digital activation by informing the value in as much detail as possible about what is the advantage of the product, which we will market through digital platforms. There are 5 types of content that can support digital activation, namely (1) educational content, (2) the latest information, (3) attractive, (4) Social Proof, and (5) About Us. From the five types of content, it can stand alone or in combination. For example, educational content is combined with attractive content, with the intention that the target market understands the content created and is able to create interactions. The ability to present products to prospective buyers is needed, so that presentation skills training is needed so that MSME actors can convey their product messages well (Anisyahrini et al., 2019). According to the DK, to create interaction in digital activation, content must contain the latest issues and be made fun and easy to understand. Building digital activation requires an interaction with 
the audience, it aims to understand what they need and what they want.

"Getting used to being adaptive and likes to innovate can be good energy to develop a business, not to stop moving and keep working until we achieve the goals we expect"

After the implementation of the activities, the authors made visits and assistance in each of the MSME actors. This activity aims to determine the development of digital activities and the obstacles that hinder them. FA as an MSME said that he had implemented what he got from community service activities. While GG revealed that he had corrected his Instagram bio, he still felt confused about creating interesting content. This is because, he runs a home business alone and no one helps him. The positive result shown by AP is that it is able to create several interactions with consumers. AP is able to sell several products and encounter consumers who are just wondering. The most difficult thing for him is making greetings that can influence consumers to buy their products.

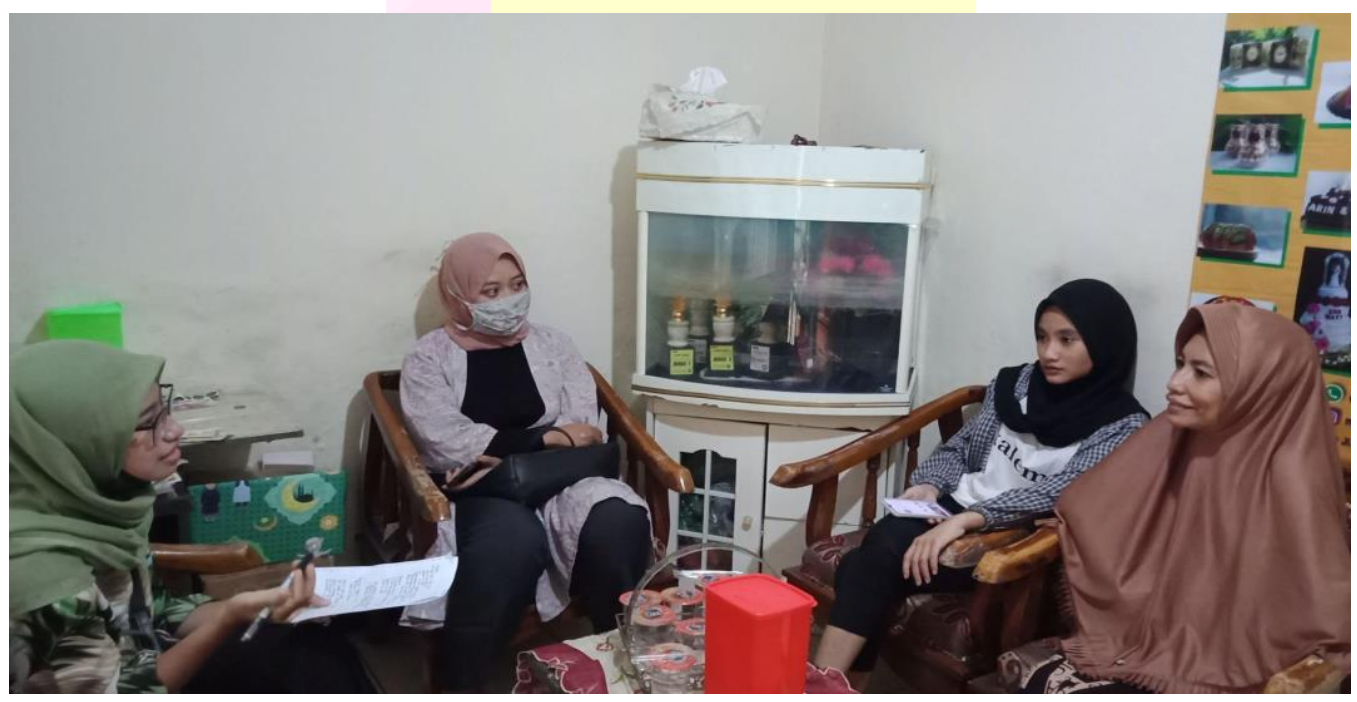

Figure 4. Visiting and Mentoring Activities

Based on the results of the visit and mentoring, MSME actors looked enthusiastic and enthusiastic during the series of activities arranged by the author.

"I am very happy to be involved in this activity, digital marketing training activities are very helpful for us. I know, what I need to improve from the marketing system that I have done so far. Turns out I had a lot of homework to do. I hope to the team, hopefully there will be a continuation of this training activity." 
Responding to some of the obstacles faced by MSME actors, the author provides a forum for consultation through the Whatsapp group for some time. Through this group, the author can monitor the activities and development of MSME actors. Participants were given the opportunity to ask questions and share experiences between participants. Overall, the author sees a better development than before. This can be proven from several recognitions of MSMEs that are able to create interactions with consumers to decide to buy their products. While many MSMEs are not yet technology literate, they are now starting to take advantage of digital platforms that they can access for free. We still have many things to evaluate from this activity, so that we can formulate short-term and long-term plans, both from the aspect of improving the quality of human resources and innovating follow-up activities.

\section{Conclusion}

The findings in several series of community service activities, namely (1) the MSME community in the arts and crafts sector received easy access to capital from Pegadaian, (2) original products and still produced manually, (3) decreased demand and income, (4) model product marketing is done in a simple way, (5) the digital marketing approach has not been carried out optimally. Some other interesting facts are that there are many MSMEs that have not determined business goals, digital platforms have not been used optimally, the digital promotion system is still very simple and product content has not been made attractively. Based on participant recognition, they began to commit to continuing to learn about the digital platforms they use and create interesting content that can create interactions with consumers. Meanwhile, due to restrictions on community activities, participants who had the opportunity to take part in training and counseling were 30 MSME actors in Malang City. The next activity is expected to increase the capacity of the number of participants, so that more benefits can be obtained by the wider community. Webinars can be an option to reach more participants.

\section{REFERENCES}

Amalia, F. N., \& Puspaningtyas, M. 
(2021). Strategi Membangun Brand Bagi Pelaku UMKM di Era Pandemi Covid-19. Prosiding National Seminar on Accounting, Finance, and Economics (NSAFE), 1(3), 1-12.

Anisyahrini, R., Wardhiani, W., Abdul Rahiem, V., \& Sutrisno. (2019). Presentation Skill Training for the Product Resellers Zoraya in Bandung. PICS-J: Pasundan International of Community Service Journal, 01(01). https://doi.org/10.23969/pics.v1i1 .1917

Arifin, Z. (2019). Kabar Baik untuk Pelaku UMKM di Malang. Liputan6.

https://m.liputan6.com/regional/r ead/4069880/kabar-baik-untukpelaku-umkm-di-malang Asmini, Sutama, I. N., Haryadi, W., \& Rachman, R. (2020). MANAJEMEN BUSINESS CYCLE SEBAGAI BASIS PELUANG USAHA PASCA COVID - 19: SUATU STRATEGI PEMULIHAN EKONOMI MASYARAKAT. Indonesian Journal of Social Sciences and Humanities, 1(2),
121-129.

Desrianto, M. (2019). Meski Tak Beken, Rupanya Peran UMKM Lebih Penting Dibandingkan Perusahaan Besar. KOMPAS.Com.

https://www.google.com/amp/s/a mp.kompas.com/money/read/201 9/08/29/174500626/meski-takbeken-rupanya-peran-umkmlebih-penting-dibandingkanperusahaan-besar

Ita. (2020). Manajemen Resiko Usaha Pada UMKM Pempek Di Kota Palembang Di Masa Pandemi Covid 19.

Kompas. (2020). Ini 3 Subsektor Ekonomi Kreatif yang Jadi Penyumbang Terbesar PDB Indonesia. Kompas.Com. https://money.kompas.com/read/2 020/08/30/151100526/ini-3subsektor-ekonomi-kreatif-yangjadi-penyumbang-terbesar-pdbindonesia.\%0APenulis : Elsa Catriana\%0AEditor: Erlangga Djumena\%0A\%0ADownload aplikasi Kompas.com untuk akses berita lebih mudah dan cepa Kompas. (2021). RI Masih Resesi, Pertumbuhan Ekonomi Minus 
0,74 Persen pada Kuartal I-2021.

Kompas.Com.

https://money.kompas.com/read/2

021/05/05/113857126/ri-masih-

resesi-pertumbuhan-ekonomi-

minus-074-persen-pada-kuartal-i-

2021? page $=$ all.

Mandasari, A. E., Harison, E. D., Sari,

D. P., \& Taufik, N. (2021). ADAPTATION OF MSMEs

BUSINESS IN NEW NORMAL CONDITIONS.

Pasundan

International Community Services

Journal (PICS-J), 03(01), 14-21.

Pratiwi, M. I. (2020). Dampak Covid-

19 terhadap perlambatan ekonomi

sektor umkm. Jurnal Ners

Universitas Pahlawan, 4(2), 30-

39.

Santoso, R., \& Mujayana, M. (2021).

Penerapan Manajemen Risiko

UMKM Madu di Kecamatan

Badas Kabupaten Kediri di

Tengah Pandemi COVID19.

Jurnal Nusantara Aplikasi

Manajemen Bisnis, 6(1), 74-85.

Suryaningprang, A., Irwan, L. N., \&

Sufyani, H. M. A. (2019). Women

Skills Improvement Training

Education Through Online Media

and Business Introduction to
SMES for Members of The PKK in the Village Ciwalen- Sukaresmi District of Cianjur Regency, West Java Province. Pasundan International COmmunity Services Journal (PICS-J), 01(01).

Thaha, A. F. (2020). Dampak Covid19 Terhadap UMKM di Indonesia. Jurnal Brand, 2(1), 147-153. 